\title{
The Drop in Crime Rates. A Multivariate Analysis of Long-Term Trends
}

\author{
Teodoro Hernández de Frutos, Esther Casares García \\ Department of Sociology, Universidad Pública de Navarra, Pamplona, Spain \\ Email: theo@unavarra.es, casares@unavarra.es
}

How to cite this paper: Hernández de Frutos, T., \& Casares García, E. (2018). The Drop in Crime Rates. A Multivariate Analysis of Long-Term Trends. Sociology Mind, 8, 25-45.

https://doi.org/10.4236/sm.2018.81003

Received: October 7, 2017

Accepted: January 13, 2018

Published: January 16, 2018

Copyright (๑) 2018 by authors and Scientific Research Publishing Inc. This work is licensed under the Creative Commons Attribution International License (CC BY 4.0).

http://creativecommons.org/licenses/by/4.0/

(c) (i) Open Access

\begin{abstract}
This paper confirms the hypothesis that crime is declining in westerns countries by analysing three representative methods of police registration of crime figures: the French "procedural "method, the "primie facie" method used in England and Wales, and the "dualize" model adopted in Spain. Based on the assumption that crime is a legal-cultural phenomenon, the main characteristics of each model are examined, and the conclusion can be reached that while comparing time series drawn up from annual figures of police recorded crime would be unrealistic, due to the historic peculiarities of each country, it is possible to compare the magnitude and the general trends and developments, as they are independent from data registration methods. The conclusion is that in the three models, it is possible to observe a fall in crime rates on a global level, the continuous emergence of types of crimes as a result of social change, improved practices in police registration and classification of data and, a growing interest among citizens in receiving reliable data.
\end{abstract}

\section{Keywords}

Crime, Police Statistics, Procedural, Primie Facie, Dualist

\section{Introduction}

Having information on crime is as basic for modern society as having information on unemployment, the retail price index, voting intentions, trends in tourism or numbers of immigrants (Mosher, Miethe, \& Hart, 2011). Not a day goes by without the media reporting on some crime or another, and indeed most media have a section dedicated to crime alone (Greer \& Reiner, 2012). The publication of statistics on police, court and judicial matters is greeted with great interest and is often used to justify demands for more resources or to publicize the efficiency of a particular policy or ministry or even the gov- 
ernment itself (Fitzgerald et al., 2012). The way a country handles crime as regards aspects like transparency and communication reflects the democratic commitment and openness of its politicians (Downes \& Morgan, 2012). However, if all social statistics can be considered difficult and controversial, then crime statistics can be considered. It could even be said they are some of the most, if not the most, difficult statistics. This is because of the nature of crime and because of the problems that arise when crimes are recorded, classified, counted and made public (Maguire, 2012). Along with murder and manslaughter, the detection and solution rates for which are virtually $100 \%$ thanks to today's scientific methods involving prints, DNA and closed circuit television. Crime includes acts that are not as easy to clarify, such as petty theft, vandalism, offences against honour and so on, which are often impossible to quantify. In addition to this, there is a big problem with reported offences because today's penal system in the West means that they cannot be considered crimes until someone has been judged and found guilty. This means that police, court and judicial crime figures differ from each other.

\section{Literature Review}

It is widely acknowledged by experts in the sociology of crime that police figures are useful (Aebi, 2010) because, although they may be of little value when it comes to making comparative analyses on a transnational level, their historical series are indeed valuable as long as any legal changes that may have taken place are taken into account. Establishing comparisons on an international level is complicated (Aebi et al., 2010). In the case of crime, the thing that makes analysis difficult is the fact that, while the police can be considered the first step in criminal proceedings, this does not mean that the figures for recorded crime accurately report the total number of cases entering the criminal justice system. In many countries, the public prosecutor's office can start criminal proceedings without receiving a police report, which means that some serious crimes are not recorded by the police but by the public prosecutor's office. However, most of the crimes included in the various penal codes are either reported to or detected by the police. Although different ministerial authorities lay down the formal framework for counting crimes, there are other aspects that are more difficult to control, e.g. a member of the public may report a crime involving a stolen bag that turns out to be just a lost bag, and this has a great impact when it comes to deciding whether or not this should be counted as a crime by the police. For this reason many doubts have arisen over the years as to the validity of police statistics (Kääriäinen \& Siren, 2011; Malby, 2010). Researchers have identified two tendencies in the way the police handle crime figures: make them lower because of an excessive workload, or make them higher by incorporating petty crimes so as to draw attention to the lack of resources and improve police performance statistics (Robert \& Zauberman, 2011).

Official measurements play an important role in understanding how crime affects individuals and communities (Rennison et al., 2011; Hough \& Sato, 2011). 
Inaccurate data distort the view of the social processes that give rise to crime in our society. Insofar as estimations comparing crime levels are imperfect, resources for controlling crime may be allocated erroneously, leaving the most disadvantaged communities and those that have not reported crimes marginalized. The fact that crimes are not reported also suggests a problematic relationship between the public and the police and implies a general lack of public trust and faith in the criminal justice system. Low crime reporting would be a significant problem even if it were distributed evenly throughout the population. In their analysis of crimes being reported to the police between 1973 and 2005, Baumer \& Lauritsen (2010) found that the United States had experienced modest increases over the last thirty years, although only $40 \%$ of non-fatal violent incidents and $32 \%$ of property crimes were reported. Using victimization data from the British Crime Survey to explore changes in the rate of reporting between 1991 and 2008, Tarling \& Morris (2010) discovered that the reporting of incidents had decreased by approximately four percentage points during those years. It appears that not reporting incidents to the police is more likely among certain populations. Huey \& Quirouette (2010) suggest that there is an "anti-snitching code" that discourages the homeless from reporting to the police. This expectation may be different for women, who are considered to be inherently more vulnerable. It is widely reported in the literature that the victimization of men is less likely to be reported than the victimization of women.

There are four basic factors affecting whether or not people report crimes to the police: 1) the seriousness of the incident, and the more serious the incident, the more likely it is to be reported; 2) the characteristics of the victim and of the incident, whereby various considerations affect whether the incident is reported to the police, e.g. man or woman, black or white, young or old, poor or well-off; 3) the relationship between the victim and the assailant, because when the assailant is known, the incident is less likely to be reported than when the assailant is a stranger; and 4) fear of reprisals, especially in the case of women when they have to report their partners for intimate violence, and in the case of young people (Rennison et al., 2011).

By sociodemographic characteristics, underreporting is more common among young people than adults. Bosick et al. (2012) found that the rate of reporting varies depending on the type of crime, but generally increases over the course of life. The characteristics of the incident, the victim and the offender all influence police reporting to varying degrees, not only between young people and adults but also between young people, adults and senior citizens. The proportion of incidents that victims report to the police increases with age. The reporting rate by those aged 12 to 15 was $26 \%$ as opposed to $55.4 \%$ among over-65 s. By analysing data collected between 1992 and 2005, the authors discovered that less than a third of violent incidents against minors were reported to the police and that violence against young blacks was the crime most likely to be reported as opposed to crimes committed against young whites or Asians. There are also numerous stratification factors that affect re- 
porting, such as race, gender, wealth and education, because they influence the victims of violent crime when they come to decide whether or not to inform the police. The variables that have the biggest impact on reporting rates are immigrant status, marital situation and race.

Another important matter is that the position of the police in the criminal justice system can have a direct effect on the number of crimes recorded and how they are classified (Hart \& Rennison, 2003). In some countries the police can work with absolute independence, while in others they may work under the close supervision of the public prosecutor or the court. The police may have the power to classify the events they investigate concerning specific crimes, but this might be done by the public prosecutor instead. This difference can affect the relative distribution of the different types of crime included in the reference manual. And when all a state's police and security forces are taken into account, there are substantial differences between countries as far as the tasks they carry out are concerned. For example, in most states the police have to monitor and report traffic offences (driving under the influence, serious injuries, speeding, parking offences), but in many countries the police have the additional task of maintaining public order and helping the public in various situations. Therefore care must be taken when police resources are considered in relation to the volume of crime recorded or the number of arrests made (Aebi et al., 2010). All the above factors determine the number of police officers in service-and the amount of crime recorded-because the more police there are, the greater the number of crimes usually recorded. As can be seen in the chart below, Spain Figure 1, exceptionally, has a very high number of police officers, possibly due to the threat of terrorism that the country has experienced for many years.

\section{Description of Models}

\subsection{The Procedural Model in France}

This is a model that puts great stress on the correct observance of all the actions involved in a crime (a list of 43 procedures), which are clearly related to the

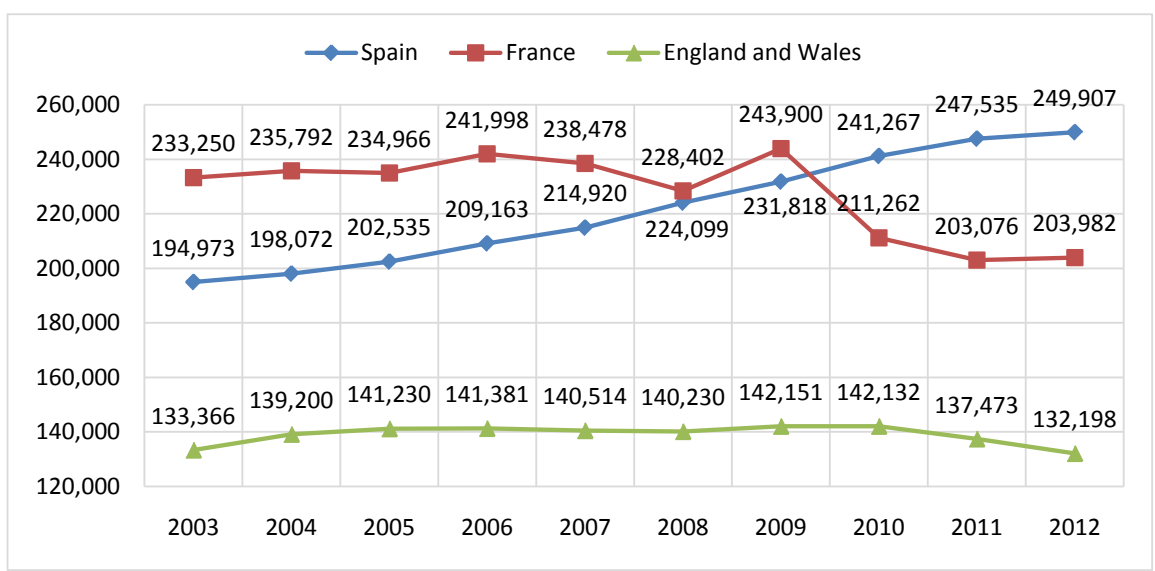

Figure 1. Number of Police officers. Source: Eurostat (2014). Trends in crime and criminal justice, 2010. Eurostat. 
stages of court proceedings. The main institutional statistics used for counting crime in France come from a monthly register of confirmed criminal acts known as "I'état 4001", which is compiled by the urban police, the national police (gendarmerie) and the Prefecture of Police in Paris (different nomenclature depending on which cities). Since its creation in 1972 l'état 4001 has provided a general report on the number of confirmed acts and, since 1985, elucidated acts (when a suspect has been arrested) for each division of the urban police and each squad of the national police. Police statistics come from around 7000 police stations (divisions) and national police officers (squads). The confirmation of a criminal act is the first stage in a judicial process that is notified to the court of justice, and the established process can then follow all possible paths of classification, although obviously a criminal act that is not brought to the attention of the urban or national police cannot appear on l'état 4001. These administrative statistics reflect the crimes people report and the actions taken by the services. Taking into account that there may be a time lag between knowing about a crime and reporting it, this means that hundreds of burglaries recorded in a month might not actually have been carried out during the month in question because the information on the commission of a crime could originate from before the month it was recorded (Aubusson de Cavarlay, 2007).

The statistics are encoded by the police in the 442 public safety divisions using an internal Ministry of the Interior application called the Systeme de Traitement de I'Information Criminelle, Faits Constatés-Élucidés (STIC-FCE), whose data collection tables contain boxes in which to record procedural questions dealt with by officers of the judiciary police, providing a statistical count record for each service. The Prefecture of Police in Paris uses a specific system called $O M E G A$ for the same task, while the national police in each of the 3607 territorial squads use a statistical information message generated by $B B 2000$ (bureautique brigade) software. Once the data have been checked by intermediate levels in the urban and national police structures, they are centralized and processed nationally by the Service Central d'Étude de la Délinquance (SCED). This central office has the task of centralizing, classifying and circulating the statistical data collected by the state'spublic safety services. The monthly data are dealt with at local level and sent to the Direction Départementale de Sécurité Publique (DDSP). After the figures from all the divisions have been checked and added together, l'état 4001 is sent to the Direction Centrale de la Sécurité Publique (DCSP) and published annually on the internet around three months after the end of year.

As mentioned earlier, the typology by which crimes are classified in France is known as l'état 4001, which comprises a nomenclature of 107 indices arranged into four broad groups-robberies, economic and financial offences, crimes against the person, and other offences (except drugs) — to which are added three aggregate areas: street crime, organized and specialized crime, and offences discovered in the line of duty. Crimes are classified in four main columns: con- 
firmed acts, elucidated acts, provisional custody (with two sub-columns: under 24 hours and over 24 hours), and persons charged due to evidence of guilt (with six sub-columns: released, held, French, foreign, men, women), which effectively makes a total of 12 columns. As far as the crime's definitive classification is concerned, the names applied to the acts do not strictly follow those in the penal code, but instead use the everyday terminology of the police services, who combine the act and the way it was carried out, e.g. armed robbery at knifepoint. The categories used are fairly heterogeneous and cover different possibilities within the same table. Hence there are 22 ways to classify the actual offences, 18 ways to describe the victim, 10 ways to refer to the how the offence was reported, 43 ways to indicate the stage of the procedure, and 6 ways to refer to the object over which the offence was committed (Ventre \& Bauer, 2011).

L'état 4001 has been cautious in methodological terms because no significant changes have been introduced over the years. This was to avoid any break in the statistics that could prevent the series from being analysed longitudinally. However, the system did undergo two minor updates in 1988 and 1995-the latter being the year after the introduction of the new penal code (1994) - which incorporated all the developments in legislation and brought about the elimination of four categories. Hence the names of the penal categories that were established at the time and which appear today on the reference document came into effect in January 1995. With this change, the number of offences dropped from 107 to 103 with the elimination of categories 96, 97, 99 and 100. Each index has its corresponding specific count unit (Tournyol Du Clos \& Rizk, 2004).

L'état 4001 has been widely criticized (Bauer, 2012, Bouillon and Quentin, 2013). One of the most notable criticisms came in the shape of a report by two members of parliament, Pandraud \& Caresche (2001), which led to the creation of a new institute whose main purpose would be to set up victimization surveys and later use the data in its reports. The criticisms were not actually directed towards the typology used by l'état 4001 , but towards the use that was made of it. It should be remembered that l'état 4001 was never intended to measure crime but to compile a police table giving an overview of their activities and initiatives, and thus the possibilities of using it for analytical purposes are very small, except for analyses of the register itself. It is therefore an inaccurate counting system because it does not allow the ways in which crime evolves and mutates to be captured in any detail. Despite having 107 indices for classifying offences, the system does not cover road safety offences or offences confirmed by other administrations such as customs, tax inspectors or work inspectors. The report by Pandraud and Caresche showed that the system gave only a partial assessment of crime, that it had little scientific basis, that it led to the politicization of public debate and that any observation of how crime was evolving consisted of comparing the figures for one year with those for another, which seriously limited the area of interpretation. Crime was a private domain characterized by an absence of transparency and open to misinterpretation, which was unworthy of a modern European democracy like France in comparison to countries like the 
United States. They believed that the institute should compile an annual report on crime and the judicial responses to it using confirmed data and victimization surveys.

Three important decisions on methodology in police statistics were adopted in 2004 with the publication of the institute's first analysis work. The first decision was to choose 1996 as the reference base year for the annual series extracted from l'état 4001 because the previous year, 1995, was the one in which the new nomenclature and new methodology guidelines established by the DCPJ were introduced. Indeed 1995 is considered to be a lost transitional year during which the new data collection practices were gradually being set up. It is also believed that by 1996 the homogeneity of data collection had already benefited from the experience acquired in 1995. This would explain why 1996 is the first year for which the Observatoire National de la Délinquance et des Résponses Pénales (ONDRP) uses statistics from l'état 4001 in their current version, and not 1995. The second decision involved the undesired effects of the political use of police statistics in the shape of the single indicator for recorded crime, which without explanation included crime units as varied as murder and theft. This led to the adoption of the Caresche-Pandraud report's recommendation suggesting that priority should be given to analysing and commenting on the figures for serious offences, but without adding them all up together. The third decision was to always avoid the "single crime figure".

\subsection{The "Prima facie" Model in England and Wales}

One of the most notable characteristics of the Anglo-Saxon model in England and Wales is the incorporation since 2002 of the "prima facie" code, which consists of recording any crime regardless of the importance the police may give it (Burrows et al., 2000). This idea can be traced back to the discovery that while some police quickly accepted incidents as crimes, adopting a "prima facie" rule, others insisted on having more evidence or more obvious evidence that a crime had been committed, adopting a "model of proof" evidential standard. After the report by the above authors, the police introduced a new procedure that required all police forces to implement the "prima facie" rule. The aim of this change was to improve the integrity and consistency of the police figures recorded and also to bring about a change in attitude on the part of the police which could make victims more willing to report crimes, knowing that their accounts of what happened were more likely to be accepted (Tarling \& Morris, 2010). It was designed to guarantee greater consistency between forces when it comes to recording crime and at the same time to focus more on the victims of the crimes recorded (Home Office, 2011).

The crimes figures are compiled using details from 43 territorial police forces and the British Transport Police. The acts registered by these services are recorded whenever anyone reports a crime or if there is police intervention, and they are all accompanied by a compulsory statement. Non-criminal incidents and attempts such as assault without injury are also recorded. The information 
thus obtained is sent to the Home Office on a monthly basis for each type of crime that appears on the list of offences. These include all the ones that could possibly be dealt with by jury, plus less serious ones such as petty theft and one or two other closely related offences. Once they have been checked and corrected, the definitive figures are provided on an annual basis in Criminal Statistics, England and Wales, while provisional figures are provided on a quarterly basis throughout the year (Home Office, 2011). This information has recently been extended in the shape of three new publications in a series known as Focus on: "Focus on Property Crime", "Focus on Violent Crime and Sexual Offences" and "Focus on cross-cutting issues" (ONS, 2013a, 2013b).

In the United Kingdom the list of categories (Recorded Crime List, RCL) that the police use to record crime and which are published by the ONS now contains 128 items after being reduced from 148 in 2012 (ONS, 2013a, 2013b). This change affected the internal distribution of the categories but not the overall count, which remains unchanged. The crime recorded by police is divided into broad categories to distinguish between crimes with a specific identifiable victim (known as "victim-based crimes") and crimes that do not normally have a direct victim and are more likely to be recorded as a result of the proactive efforts of the police and other authorities ("miscellaneous crimes against society"). These categories have been introduced to improve the clarity of presentation and comparability with data from the crime survey of England and Wales. Examples of 'victim-based crimes' include an attack or assault on an individual, a burglary or act of vandalism in someone's home or a robbery in a company.

Great stress has also been placed on the homogeneity of the figures when recorded by different police units, i.e. that the acts that occurred should be recorded and classified uniformly. Given the difficulty inherent in classifying a criminal act and the fact that there were various different sets of rules, it was suggested that the practices for recording crime followed by the different police forces of England and Wales should be unified (Flatley et al., 2010). The new procedure was designed as a substitute for the previous procedure known as National Crime Recording (NCR) after very serious flaws were detected that cast doubts over the whole system. These included wrongly classified crimes, unclassified crimes, inaccuracy in the number of crimes recorded, inappropriate reclassification of previously recorded crimes, and an error rate between the crimes recorded by different police forces that ranged between $15 \%$ and 65\% (Shute, 2013). When it was introduced it brought about numerous changes and a significant divergence from the national victimization survey between 2001 and 2004-while police records showed an increase in crime, the survey showed a decrease (Home Office, 2011).

The changes became more urgent after an influential report (Burrows et al., 2000) revealed significant differences between police forces as regards the criteria followed for recording incidents. The changes brought by all these reforms included the following: a) all incidents notified from whatever source and regardless of whether or not a crime is reported must be recorded by the police; $b$ ) 
the incident must be recorded as a crime (notifiable offence) if on the balance of probability the circumstances are denoted as a crime in the legislation and there is no credible evidence to the contrary; and c) a crime must always be recorded unless there is additional evidence refuting what occurred (Jones, 2009). However, introducing the reforms was not easy. As the Audit Report (2004) shows, in 2003 just 17 out of 43 police forces had complied with the new rules.

In England and Wales over the last few decades there have been frequent important changes not only in the number of categories on the crime list but also in the recording of crimes. These came about after it was confirmed that the official crime statistics were affected by the crime typology used and by different police recording practices. An early report by the Perks Committee brought a change in the way crimes were counted in 1971. Another change came in April 1998 when the crime list was expanded to include certain additional summary offences and counts became more victim-based, i.e. the number of victims was counted rather than the number of crimes. The introduction of new crime categories known as the National Incident Category List (NICL) increased the number of so-called 'notifiable offences', i.e. those that the police have to notify to the Home Office for inclusion in the national crime statistics (UK Statistics Authority, 2010).

In 2006 the Smith Review looked at the changes that would have to be made to the production and release of crime statistics so as to restore public confidence. Public confidence in crime statistics can be undermined by any of the following elements: the presentation of statistics that are perceived to be in conflict with the direct personal experiences of the public; the presentation of statistics that use categories or definitions that do not coincide with the common-sense interpretations of the public; the presentation of contradictory statistics that seem to be open to widely differing interpretations; a lack of coverage of important areas of criminal activity and victims; and interference by the police or the Home Office in the production and presentation of the statistics. The numerous recommendations it made included increased coverage of crime survey data, an audit of police figures, improved presentation of the national statistics and greater separation between statistics and the political class. It also stressed that the orientation of crime statistics should be changed from a national aggregate image to the provision of local figures.

\subsection{The Dualized Model in Spain}

The Spanish system resembles the UK system insofar as its territory is divided into various operational jurisdictions as regards the police. However, while the UK has opted to present results separately, in Spain there seems to be no definite policy. In some years the data for Catalonia, the Basque Country and Navarre are not included, but then other (more recent) years have seen a return to the integrated structure whereby joint figures are provided for the Ministry of the Interior (MIR) and the three autonomous communities that have their own police forces and their own statistics. The fact that both the national police and the 
autonomous regional police operate in these communities makes counting even more complicated. It can also be said that the system is a dualized one because the figures are presented broken down into crimes and misdemeanours, which might have its advantages in that it establishes a kind of gradient to the incidents, but it also has its disadvantages in that it is very difficult to compare the figures with those of other countries. The variables and categories used in police statistics have gradually been adapted to the penal reforms that have been introduced, the most far-reaching of which was the new Penal Code of 1995 (Díez, 2004). As a result of changes in the basic organizational structure of the Ministry of the Interior, the Office of Coordination and Studies has now taken on the task of producing crime statistics, which had previously been done by another department. Regulations governing national crime statistics were passed on 31 January 2013, thereby giving the seal of approval to the new crime system and providing guidelines in relation to it.

The standard forms for crime statistics are completed by the officials who in each case initiate the relevant proceedings (in the Guardia Civil this is done at local post level, and in the police at the corresponding police, group or squad inspector level). Once the forms have been completed but before they are recorded, the data are checked over by statistics staff. After the data have been checked, they are recorded and saved to the respective central information services of the police or Guardia Civil. When these processes are finished, the statistics departments of both forces send the data on a monthly basis to the Office of Coordination and Studies of the Secretary of State for Security so they can be processed by their statistics staff. The same thing happens to the data for the autonomous regional police forces (Pérez, 2012). The classification used is composed of 172 sections divided into 30 broad categories. The data show the origin of the action, the current proceedings, the action taken by the police, the date and time of the event, the location of the event, a description of the event, the degree to which it was executed, the solution of the case, the resources used, the modus operandi and the authors.

Data is collected via the use of two types of form: police actions and arrests. These two forms include around 80 variables, 5 of which form a link between the two. At least a police actions form has to be completed for each police intervention that takes place that leads to the institution of proceedings. In the case of known events, regardless of the degree of execution (committed or attempted), all the sections on the police actions form relating to the event will need to be completed, which means that when various offences are included in the same proceedings, a different form has to be used for each one. When knowledge of the event and its solution occur simultaneously, just one police actions form is needed. However, if it is a question of additional information regarding an event that has already been recorded as known or solved, a new form has to be completed including information about the original event.

The actions file contains details of known events, solved events, victims and objects seized. The offenders file contains details of the roles played by the dif- 
ferent people involved in the police system (the arrested, the accused, etc.) and the variables relating to the event that occurred. When it comes to compiling the records in the Crime Statistics System (SEC), as a general rule a count will be made of events known in the first instance-as contained in statements taken and as shown in all other interventions regarding administrative offences or events of interest to the police-by the National Police Corps, the Guardia Civil, the Ertzaintza (in the Basque Country), the Mossosd' Esquadra (in Catalonia), the Policía Foral (in Navarre) and any local police who are members of the SEC.

The statistical use of the data concerns mainly the location where the event occurred and the date proceedings were instituted, although they may also be useful for other items such as the investigating police squads or units. Every time that proceedings are instituted in a police unit as a result of a criminal offence, or proceedings in the administrative area or regarding events of interest to the police, or proceedings that are instituted as a result of the arrest, accusation or identification of any of the persons involved in the events, or proceedings for any infraction of Law 1/92, a record of actions must always be completed or generated, along with a record of offenders if appropriate. Alongside statistics for the national police, whose jurisdiction is limited to urban areas, and the Guardia Civil, who are more involved with rural areas and are military in character, there are also statistics for the autonomous regional police, as we have already seen. In the context of the territorial division of the state into 17 autonomous communities, three of these autonomous communities decided to set up their own police forces: Catalonia (Mossosd' Esquadra), the Basque Country (Ertaintza) and Navarre (Policía Foral de Navarra).

With the introduction of the new Crime Statistics System (SEC) on 1 January 2008, the procedures were improved by reducing one of the intermediate steps, namely the generation of the police forms. The most notable changes in the new system include an increase in the statistical variables obtained, the inclusion of a By Ministerial Order tag on files containing personal details, improvements in technical and computer procedures, etc. The crime statistics are obtained according to the following outline: 1) police units find out about an event; 2) specific police actions are carried out and documented; 3) specialist staff enter the data into the computer using specially-designed software in the case of the National Police Corps, or in the case of the Guardia Civil, via the SIGO application, whereby any user can statistically record an event while carrying out police procedures; 4) the monthly statistics are sent to the Secretary of State for Security between the $10^{\text {th }}$ and 15th of the following month, using either the company intranet or cryptographically secure emails; and 5) the files sent by each police force are processed and the relevant reports produced.

There have been numerous criticisms of the Spanish system, culminating in a manifesto signed by various criminologists which questioned its secrecy, the accuracy of its data and the way they were accessed, complaining that the general crime figures compiled by the Ministry were far from being open-access infor- 
mation for the public in general and for the scientific community in particular, and that until 2006 the data provided on the Ministry of the Interior website were very difficult to find. In an article entitled "The mystery of the disappearing Spanish police statistics", Aebi \& Linde (2010) argue that the statistics are incomplete and have serious problems as regards accuracy because of the large number of errors, such as fluctuations in the figures presented in the yearly reports - the information for Catalonia disappeared from the MIR yearly report in 2006, the data for the Basque Country disappeared in 2007, and the figures for Navarre were never even fully integrated. There are problems with the evolution of the figures for murders in Spain over the period 2000 to 2007 because according to the MIR yearly report for 2000 there were 1158, whereas the quarterly reports for the year add up to a total of 1247. The figures for 2004 do not even include the 191 murders and 1857 attempted murders that occurred in the Madrid train bombings of 11 March.

\section{Data 1}

Because of cultural differences in the concept of crime that have become deeply ingrained in the legal system, comparing crime data on a transnational level is virtually impossible (Harrendorf et al., 2010; Pérez \& Benito, 2013), even when it is between three systems in countries that are as close as the ones we are analysing here. It is not just that the categories are different, but also the way the data are calculated: victims, assailants, means, places (Lewis, 2012). However, it is at least possible to analyse how the data evolve and how they are presented. In this respect it has to be said that the statistics in France and in England and Wales are easy to access and publicly available. They are to be found in their respective yearly reports along with the relevant reports on which the statistics are based, and are also supplied in advance every month over the course of the year. In the case of Spain there is a structural shortfall in this area because, although the data are also open-access and can be found in yearly reports and on the internet, there is much less information. To find out details about the methodology used, a specific request has to be made because they are not published and it is therefore difficult to cite them. It is also difficult to carry out a longitudinal analysis given that some years include figures for the autonomous regional police and some do not. The number of police officers for the three systems is at least a figure to take into account; in 2010 in Spain there were 241,267 (508 per 100,000 inhabitants), a proportion almost twice that of France with 211,262 (354 per 100,000 inhabitants) and England and Wales with 142,132 (259 per 100,000 inhabitants).

In France (see Table 1) the total number of crimes and the number of murders have fallen since 2007. In 2011, the proportion of crimes against physical integrity was over 7 per 1,000 inhabitants, but the upward trend is slowing down. Between 2006 and 2008 the rate remained stable, but it rose again in 2009 and stabilized at 7.4 in 2010. There were 350,040 cases of fraud and economic 
Table 1. Crime evolution in France.

\begin{tabular}{|c|c|c|c|c|c|c|c|}
\hline & 2006 & 2007 & 2008 & 2009 & 2010 & 2011 & $\begin{array}{r}\text { Variatio } \\
2006-2011\end{array}$ \\
\hline Homicides & 879 & 826 & 839 & 682 & 675 & 743 & -136 \\
\hline $\begin{array}{l}\text { Crimes against } \\
\text { physical integrity }\end{array}$ & 434.183 & 433.284 & 443.671 & 455.911 & 467.348 & 468.012 & 33.829 \\
\hline Sexual violence & 22.864 & 23.247 & 24.031 & 23.253 & 22.963 & 23.871 & 1.007 \\
\hline Total Property crime & 2534.097 & 2363.519 & 2243.498 & 2.227 .649 & 2184.460 & 2146.479 & -387.618 \\
\hline Thefts & 2040.335 & 1901.124 & 1805.876 & 1.816 .508 & 1803.993 & 1804.598 & -235.737 \\
\hline Thefts with violence & 127.190 & 112.885 & 106.969 & 112.909 & 121.192 & 120.966 & -6.224 \\
\hline Thefts sans violence & 1913.145 & 1788.239 & 1699.243 & 1703.743 & 1682.955 & 1683.632 & -229.513 \\
\hline Thefts motorized car & 744.245 & 694.981 & 640.400 & 629.802 & 594.137 & 552.125 & -192.120 \\
\hline $\begin{array}{c}\text { Thefts without } \\
\text { vehicles }\end{array}$ & 165.805 & 163.845 & 169.499 & 166.615 & 172.103 & 173.454 & 7.649 \\
\hline $\begin{array}{c}\text { Thefts avec armes } \\
\text { blanches }\end{array}$ & 11.421 & 9.897 & 8.749 & 9.090 & 9.5513 & 8.939 & -2.482 \\
\hline $\begin{array}{l}\text { Thefts violent } \\
\text { sans arme }\end{array}$ & 110.010 & 97.694 & 91.777 & 96.601 & 105.327 & 106.301 & -3.709 \\
\hline $\begin{array}{l}\text { Burglaries and } \\
\text { thefts stratagem }\end{array}$ & 346.044 & 322.237 & 307.744 & 320.418 & 323.954 & 341.895 & -4.149 \\
\hline Burglaries & 335.052 & 312.384 & 298.173 & 311.300 & 316.084 & 333.338 & -1.714 \\
\hline Burglary in a dwelling & 164.766 & 150.624 & 151.737 & 164.150 & 172.150 & 172.497 & 7.731 \\
\hline Rape & 60.348 & 60.378 & 62.724 & 69.284 & 70.764 & 67.529 & 7.181 \\
\hline Robbery offences & 127.190 & 112.885 & 106.633 & 112.765 & 121.038 & 120.966 & -6.224 \\
\hline $\begin{array}{l}\text { Destructions, } \\
\text { dégradations }\end{array}$ & 493.762 & 462.395 & 437.622 & 411.141 & 380.467 & 341.881 & -151.881 \\
\hline $\begin{array}{l}\text { Fraud and economic } \\
\text { and financial offences }\end{array}$ & 334.064 & 320.417 & 354.485 & 370.728 & 354.656 & 350.040 & 25.976 \\
\hline Fire voluntary & 43.943 & 46.032 & 41.085 & 45.582 & 43.568 & 40.244 & -3.699 \\
\hline Attack bombing & 348 & 306 & 167 & 124 & 145 & 110 & -238 \\
\hline $\begin{array}{l}\text { Destructions and } \\
\text { dégradations }\end{array}$ & 449.471 & 416.057 & 396.370 & 365.435 & 336.754 & 301.527 & -147.944 \\
\hline Total crime & 3725.588 & 3589.293 & 3558.329 & 3521.256 & --- & --- & \\
\hline Variation simple & & -136.295 & -30.964 & -37.073 & & & -204.332 \\
\hline Variation \% & & 3.65 & 0.86 & 1,04 & & & -5.48 \\
\hline
\end{tabular}

Fuente: État 4001. En ONDRP (2012). Repport 2012. Pág. 501-504 and Eurostat (2015). Social statistics.

and financial offences confirmed by the police and the gendarmerie in 2011. These offences were on the rise between 2005 and 2008, when the rate reached more than 6 confirmed cases per 1000 inhabitants, thus approaching the maximum rate recorded in 2001. However, since 2009 the rate has followed a constantly downward trend that can be attributed to changes in the rules for recording certain types of incidents. Around 10 offences involve swindles, the abuse of trust, forgery and the use of cheques and credit cards. The rules for re- 
cording some of the offences under this indicator have changed several times since the second half of 2009. "Credit card fraud", "fraud and abuse of trust" and "forgery and use of credit cards" are no longer recorded as they used to be. This is a controversial area because a number of jurists believe that if a fraudulent act has taken place when the holder of the bank account was not in physical possession of a credit card, the complainant should be the bank and not the account holder, i.e. the bank will be reimbursed and the assets of the account holder should not be affected. The two indices 'fraud' and 'economic and financial offences' in 2011 included 199,408 cases of fraud and abuse of trust (57.0\%) and 47,448 cases of forgery and use of credit cards (13.6\%), which means that over $70 \%$ of the indicator has been subject to changes in the recording rules, and this is considered a statistical break. For the first time since 2006 the numbers of stolen cheques and forgeries has fallen and, with fewer than 60,000 confirmed cases, are at a five-year low. The proportion of this type of offence fell to around $27 \%$, i.e. 6307 fewer confirmed cases. Economic and financial offences increased by 15.3\% in 2011 after two consecutive years on a downward trend, i.e. 3699 additional offences. Between 2006 and 2007, these two increases fluctuated between $8.8 \%$ and $6.2 \%$. From 2006 to 2011, economic and financial offences increased by over $21 \%$ ( 4843 additional recorded cases).

In England and Wales (see Table 2), events that come to the knowledge of the police are recorded whenever they are likely to involve trial by jury (indictable offences). Other similar offences are also included, such as assault without injury, which are not counted in other countries. Attempted offences are also recorded. Offences against human life committed through negligence in road traffic accidents and as a result of reckless driving are recorded, unlike in France. Accidental acts of violence can be counted even if there is no minimum threshold of injury or lost working days. Domestic violence does not have an index of its own. The Office for National Statistics distinguishes between violence against the person and sexual abuse (sexual offences), which are included under the indicator for "victim-based crime", and crimes against property. Robberies with violence (robbery offences) figure under crimes against property, robberies, violence against the person and violence. One important point is that the data cover the year from July to June as opposed to natural years, which creates problems when it comes to analysing them.

These two countries have seen a drop in total crimes and the number of murders since 2007. Of the 2,729,525 crimes against property in $2011 / 12$, $77 \%$ involved robbery or theft. Burglaries accounted for 501,053 cases representing $18 \%$ of the indicator, theft involving motor vehicles accounted for $15 \%$ and shoplifting $11 \%$. There were also 100,589 thefts from the person (3.6\% of the indicator), of which 74,690 involved violence (2.7\% of the total). Other crimes against property include criminal damage and arson ( $23 \%$ of the total). There were a total of 98,642 offences against property in 2010/2011 (down 3.5\%), which means that the downward trend seen over previous years is continuing, although at a slower rate for the second consecutive year (down 4.3\% between 2009/10 and 
Table 2. Crime evolution in England and Gales.

\begin{tabular}{|c|c|c|c|c|c|c|c|}
\hline & $2006 / 07$ & $2007 / 08$ & $2008 / 09$ & $2009 / 10$ & $2010 / 11$ & $2011 / 12$ & $\begin{array}{c}\text { Variation } \\
2006-12\end{array}$ \\
\hline Homicide & 758 & 773 & 663 & 618 & 638 & 530 & -228 \\
\hline $\begin{array}{c}\text { Criminal damage } \\
\text { offences }\end{array}$ & 1185.040 & 1036.356 & 936.361 & 806.647 & 701.000 & 631.221 & -553.819 \\
\hline $\begin{array}{l}\text { Violence against the } \\
\text { person }\end{array}$ & 506.594 & 452.609 & 420.980 & 401.629 & 368.647 & 338.445 & -168.149 \\
\hline $\begin{array}{l}\text { Violence against the } \\
\text { person without in }\end{array}$ & 539.573 & 508.822 & 482.497 & 469.790 & 453.310 & 424.070 & -115.503 \\
\hline $\begin{array}{c}\text { Most serious sexual } \\
\text { crime }\end{array}$ & 43.738 & 41.521 & 40.749 & 43.439 & 45.271 & 44.394 & 656 \\
\hline Other sexual offences & 13.784 & 12.045 & 10.680 & 10.916 & 9.648 & 9.271 & -4.513 \\
\hline Total Property crime & 3952.521 & 3553.144 & 3352.960 & 3031.767 & 2897.891 & 2796.076 & -1156.445 \\
\hline Total robbery & 2669.205 & 2446.122 & 2333.570 & 2147.984 & 2127.167 & 2098.304 & \\
\hline Robbery offences & 101.376 & 84.773 & 80.130 & 75.105 & 76.189 & 74.690 & -26.686 \\
\hline Rape of a female & 12.624 & 11.664 & 12.133 & 13.911 & 14.589 & 14.767 & 2.143 \\
\hline Rape of a male & 1.150 & 1.009 & 963 & 1.173 & 1.303 & 1.274 & 124 \\
\hline $\begin{array}{c}\text { Total Burglary } \\
\text { offences }\end{array}$ & 622.012 & 583.710 & 581.584 & 540.660 & 522.683 & 501.053 & -120.959 \\
\hline Burglary in a dwelling & 292.260 & 280.696 & 284.431 & 268.610 & 258.165 & 245.317 & -46.943 \\
\hline $\begin{array}{c}\text { Burglary in a building } \\
\text { other }\end{array}$ & 329.752 & 303.014 & 297.153 & 272.050 & 264.518 & 255.736 & -74.016 \\
\hline $\begin{array}{l}\text { Offences against } \\
\text { vehicles }\end{array}$ & 765.015 & 656.453 & 591.853 & 494.894 & 449.616 & 417.444 & -347.571 \\
\hline Other theft offences & 1180.802 & 1121.186 & 1080.003 & 1037.325 & 1078.679 & 1105.117 & \\
\hline Theft from the person & 114.852 & 101.660 & 89.652 & 92.247 & 92.902 & 100.589 & \\
\hline $\begin{array}{c}\text { Fraud and forgery } \\
\text { offences }\end{array}$ & 199.652 & 155.439 & 163.159 & 152.241 & 145.913 & 141.241 & -58.411 \\
\hline Drug offences & 194.233 & 229.913 & 243.536 & 235.596 & 232.922 & 229.103 & 34.870 \\
\hline $\begin{array}{c}\text { Other miscellaneous } \\
\text { offences }\end{array}$ & 75.739 & 69.449 & 71.166 & 70.130 & 67.055 & 60.263 & -15.476 \\
\hline Total crimes & & 4952.276 & 4702.698 & 4338.372 & 4150.097 & 3976.312 & \\
\hline Variation simple & 5427.558 & 475.282 & 249.578 & 364.326 & 188.275 & -173.785 & $\begin{array}{l}-1431.240 \\
-26.73\end{array}$ \\
\hline Variation \% & & -8.7 & -5.0 & -7.7 & -4.3 & -4.1 & \\
\hline
\end{tabular}

From: Home office (2005). Crime in England and Wales. Several years. London. Home Office and Eurostat (2015). Social statistics. y Statistic in focus (2013).

$2010 / 2011$, i.e. $-8.4 \%$ on average over the three previous years). These offences have been decreasing steadily since 2002/03 (-40\%).

Criminal damage offences continue to decrease significantly at a greater rate than other crimes against property, with 69,779 fewer cases in 2011/2012 than in $2010 / 2011$, i.e. a decrease of almost $10 \%$ in a year. Relatively stable, they decreased by an average of $12 \%$ a year between $2006 / 07$ and 2010/2011. There were 631,221 cases of robbery with force or threat of force in 2011/2012, a decrease of over $46 \%$ since $2006 / 2007$. Roughly two out of five offences of this type in 
2011/2012 involved motor vehicles. Robbery and theft in general amounted to $2,098,304$ cases in $2011 / 2012$, a decrease of $1.4 \%$ over the previous year $(28,863$ fewer cases) and a drop of $21.4 \%$ since $2006 / 2007$. This decrease is similar to the previous year's and shows that the downward trend recorded between 2006/07 and 2009/10 (an average drop of 6\% annually) was slowing down. Burglaries in dwellings, shops and other premises continued to fall between 2010/2011 and $2011 / 2012$, showing a drop of $4.1 \%$ in a year (down $5 \%$ for dwellings and down $3 \%$ for other types of premises). This confirms that the downward trend for this type of crime was levelling off between 2010/2011 - the decreases observed between $2009 / 2010$ and 2010/2011 were in the order of 7\% (924,400 fewer cases). Over five years there were 120,959 fewer burglaries (down 19.4\%). The drop in vehicle-related theft incidents continues along the same lines as in previous years (down 7.2\% in 2011/2012 and 2010/2011 with 32,172 fewer cases, which means 9.1\% down on the previous year).The decrease in this type of offence helps explain much of the drop in overall thefts because it represents more than half of those that took place between $2006 / 07$ and 2011/2012. Of the 570,901 fewer confirmed robberies during this period, 347,571 were vehicle-related. However, thefts from the person, which had stabilized between 2009/2010 and 2010/2011 (up 0.7\%), rose sharply between 2010/2011 and 2011/2012 (up 8\%), with 7.687,7 more cases recorded. This is a progressive increase since $2008 / 2009$, although it follows a continuous downward trend every year since 2002/2003. Total property crime like vandalism of personal and household property at 51.2 cases per 1,000 inhabitants shows a decrease of 20.5 points over five years if we compare it to the figures for $2006 / 2007$ (71.7 cases per 1000).

In Spain (see Table 3), overall crime and the number of homicides have decreased since 2007. 2011 saw a drop in the number of crimes against property, reclassified under Heading XIII of the Penal Code as "crimes against property and against the socioeconomic order": robbery, criminal damage, economic and financial frauds and offences, fraud, offences against intellectual and industrial property, frauds against the market and consumers, receiving, money laundering, financial offences, etc. Robberies without violence or infraction (petty thefts) involving goods valued at less than 400 euros are not included because they are not crimes but misdemeanours. There were 817.391 crimes against property in 2012, 1.5\% less than in 2011 and 3.4\% less than in 2007. In $201152 \%$ of them were burglaries or vehicle-based theft (breaking and entering), 19\% were simple thefts (petty theft), $11 \%$ were robberies with violence and $6 \%$ were thefts from vehicles. The remaining $12 \%$ was made up of swindles, economic and financial offences, and criminal damage. The 714.968 robberies recorded in 2012 represent a decrease of $0.75 \%$ compared to 2011 (5.368 fewer offences). This turnaround is the result of the decrease in robberies without violence. Between 2007 and 2012, overall robberies dropped by 1.2\% (45,267 fewer offences) as a result of the downward trend in robberies both with and without violence. Robberies without violence evolved in different ways depending on the type of 
Table 3. Crime evolution in Spain.

\begin{tabular}{|c|c|c|c|c|c|c|c|}
\hline & 2007 & 2008 & 2009 & 2010 & 2011 & 2012 & $\begin{array}{l}\text { Variation } \\
2007 / 2012\end{array}$ \\
\hline Homicide & 388 & 414 & 412 & 401 & 385 & 364 & 24 \\
\hline Homicide Attempt & 904 & 880 & 828 & 776 & 825 & 738 & -166 \\
\hline Propriety crime & 833.593 & 879.884 & 852.380 & 832.312 & 804.573 & 817.391 & -16.202 \\
\hline Robbery & 718.292 & 742.935 & 701.112 & 730.254 & 709.600 & 714.968 & -3.324 \\
\hline $\begin{array}{c}\text { Robbery without vi- } \\
\text { olence }\end{array}$ & 629.696 & 650.103 & 610.705 & 645.843 & 621.882 & 618.361 & -11.335 \\
\hline Robbery offences & 395.753 & 418.320 & 403.652 & 443.772 & 414.937 & 405.939 & 10.186 \\
\hline Burglary in a dwelling & 81.964 & 93.880 & 97.834 & 111.656 & 100.779 & 126.422 & 44.458 \\
\hline Burglary in a building & 93.801 & 98.877 & 92.342 & 88.342 & 67.220 & 68.146 & -25.655 \\
\hline Thefts motor vehicle & 98.178 & 85.640 & 69.089 & 57.506 & 51.798 & 47.125 & -51.053 \\
\hline Robbery & 135.765 & 146.143 & 137.964 & 144.565 & 155.113 & 165.297 & 29.532 \\
\hline Robbery offences & 88.596 & 92.832 & 90.407 & 84.411 & 87.718 & 96.607 & 8.011 \\
\hline Robbery with violence & 61.957 & 63.504 & 61.836 & 58.930 & 58.472 & 67.436 & 5.479 \\
\hline $\begin{array}{c}\text { Fraud and forgery } \\
\text { offences }\end{array}$ & 115.301 & 136.949 & 151.268 & 102.058 & 95.775 & 102.423 & -12.878 \\
\hline $\begin{array}{l}\text { Violence against the } \\
\text { person }\end{array}$ & 216.127 & 231.312 & 226.033 & 217.057 & 224.625 & 228.443 & 12.316 \\
\hline $\begin{array}{l}\text { Violence against the } \\
\text { person—-without injury }\end{array}$ & 127.531 & 138.480 & 135.626 & 132.646 & 136.907 & 138.616 & 11.185 \\
\hline Family offences & 63.501 & 67.425 & 68.492 & 77.577 & 79.994 & 77.226 & 13.725 \\
\hline Damage offences & 15.737 & 18.831 & 18.507 & 18.286 & 17.904 & 17.005 & 1.268 \\
\hline Sexual crime & 10.224 & 11.797 & 10.689 & 9.957 & 9.892 & 9.008 & -1.216 \\
\hline Violent crime & 36.777 & 39.133 & 36.698 & 25.649 & 28.034 & 27.485 & -9.292 \\
\hline $\begin{array}{l}\text { Robbery violent or } \\
\text { intimidation }\end{array}$ & 88.596 & 92.832 & 90.407 & 84.411 & 87.718 & 96.607 & 8.011 \\
\hline Total crime & 2309.859 & 2396.890 & 2339.203 & 2297.484 & 2285.525 & 2268.867 & \\
\hline Variation simple & & 87.031 & -57.687 & -41.719 & -11.959 & -16.658 & -40.992 \\
\hline Variation \% & & 3.76 & -2.40 & -1.78 & -0.52 & -0.72 & -1.77 \\
\hline
\end{tabular}

Ministerio del interior-secretaria de estado de seguridad-gabinete de coordinacion y estudios and Eurostat (2015). Social statistics.

robbery; between 2011 and 2012 there was a fall in the number of burglaries and thefts from vehicles (down 6.5\%) and in the number of vehicle-based robberies (down 9.9\%), but other robberies excluding petty theft increased (up 7.3\%). In 2012, 52\% of them were burglaries or vehicle-based theft (breaking and entering), $19 \%$ were simple thefts (petty theft), $11 \%$ were robberies with violence and $6 \%$ were thefts from vehicles. The remaining $12 \%$ was made up of swindles, economic and financial offences, and criminal damage.

\section{Conclusion}

The crime figures, Table 4 for all three systems considered here appear to corroborate the theory that crime is decreasing internationally (Vollaard \& 
Table 4. Total crimes ratios variation 2003-2012.

\begin{tabular}{cccccccccc}
\hline & Number & Means & $\begin{array}{c}\text { Standard } \\
\text { deviations }\end{array}$ & Mínimum & Máximum & $\begin{array}{c}\text { Variation } \\
1991-2012\end{array}$ & $\begin{array}{c}\text { Variation } \\
2003-2012\end{array}$ & $\begin{array}{c}\text { Variation } \\
2007-2012\end{array}$ & $\begin{array}{c}\text { Variation } \\
2011-2012\end{array}$ \\
\hline Spain & 18 & 2.038 & 0.2832 & 1.544 & 2.396 & +723.892 & +124.712 & -40.992 & -16.658 \\
France & 15 & 3692.997 & 0.1573 & 3493.442 & 3974.694 & $-360.638^{*}$ & $-453.438^{*}$ & -68.037 & -1220.939 \\
United Kingdom & 18 & 4972.980 & 0.6098 & 3731.338 & 6013.759 & -1794.917 & -2282.421 & -291.915 \\
\hline
\end{tabular}

Hamed, 2012; Tseloni et al., 2010). There are competing hypotheses and no single definitive explanation for the fall in crimes and it seems likely that a number of different factors have contributed, in different ways, although there is broad support for the impact of improved vehicle and household security. The wide range of explanations include: the presence of video camera in car parks, local crime reduction initiatives, reductions in the real value of many household items, social change and controls, a strong economy, improvements in police performance and increases in police numbers (the latter being cited by Vollaard \& Hamed, 2012. Farrell et al. (2010) discuss competing theories for declining crime trends and offer a range of alternative hypotheses including more speculative ones such as car crime being a key "debut crime" such that vehicle crimes have become more difficult with improved car security which has generally inhibited criminal careers. They also identify emerging forms of crime (e.g. internet-related including ecommerce) that are not adequately captured in police figures or existing survey based measures.

Due to the idiosyncrasies of the different crime-recording models, it is not a good idea to make comparisons of crime figures between different countries. However, the evolution of these figures can be analysed and valid conclusions reached for each country. Of the three police statistics systems, those in England and Wales and France are notable for their reforms, information and availability to the public, and because they have tackled important methodological issues. Some very significant steps have been taken in France to modernize a counting system that was obsolete and dubbed prehistoric. The creation of the Observatoire National de la Délinquanceetdes Résponses Pénalesas a result of a report by two members of parliament gave rise to important reforms, including autonomy from political power and the introduction of an annual national victimization survey that serves as a counterpoint to the police figures. For many years the police statistics in England and Wales have been considered worthy of imitation. These statistics have their counterpoint in the data from the Crime Survey for England and Wales, an initiative imported from the United States. Police statistics in Spain have been conditioned by terrorism and the incorporation of three regional police forces. However, there is a need for far-reaching political debate like that which took place in the other countries included in this study. The most urgently needed changes would be the creation of a definitive geographical space, the standardization of data collection and the homogenization of the information systems used. There is also a pressing need for a national victimiza- 
tion survey to be set up, which could be organized by the National Institute of Statistics or the Centre for Sociological Research.

\section{References}

Aebi, M. (2010). Methodological Issues in the Comparison of Police-Recorded Crime Rates. In S. Shoham, P. Knepper, \& M. Kett (Eds.), International Handbook of Criminology (pp. 211-222). Boca Raton, FL: CRC Press. https://doi.org/10.1201/9781420085525-c8

Aebi, M. F., Aubusson de Cavarlay, B., Barclay, G., Gruszczyńska, B., Harrendorf, S., Heiskanen, M., Vasilika, H., Jaquier, V., Jehle, J.-M., Killias, M., Shostko, O., Smit, P., \& Pórisdóttir, R. (2010). European Sourcebook of Crime and Criminal Justice Statistics-2010. Den Haag: Boom Juridische Uitgevers.

Aebi, M., \& Linde, A. (2010). El misterioso caso de la desaparición de las estadísticas policiales españolas. Revista Electrónica de Ciencia Penal y Criminología. RECPC 12-07.

https://www.researchgate.net/profile/Antonia_Linde/publication/50514034_El_misteri oso_caso_de_la_desaparicion_de_las_estadisticas_policiales_espanolas/links/09e41514 2d16b68238000000.pdf

Aubusson de Cavarlay, B. (2007). Des comptes rendus à la statistique criminelle: C'est l'unité qui compte. (France, $\mathrm{xix}^{\mathrm{e}}-\mathrm{xx}^{\mathrm{e}}$ siècles). Historie et Mesure, 22, 39-73.

Audit Report (2004). Annual Report and Accounts.

Bauer, A. (2012). Criminalité et délinquance enregistrées en 2011. Bulletin pour l'année 2011. Observatoire National de la Délinquance et des réponses pénales.

Baumer, E., \& Lauritsen, J. (2010). Reporting Crime to the Police, 1973-2005: A Multivariate Analysis of Long-Term Trends in the National Crime Survey (NCS) and National Crime Victimization Survey (NCVS). Criminology, 48, 131-185. https://doi.org/10.1111/j.1745-9125.2010.00182.x

Bosick, S., Rennison, C., Gover, A., \& Dodge, M. (2012). Reporting Violence to the Pólice: Predictos through the Life Course. Journal of Criminal Justice, 441-451. https://doi.org/10.1016/j.jcrimjus.2012.05.001

Bouillon, C., \& Quentin, D. (2013). Rapport d'infromation relative á la mesure statistique des délinquance et de leur consequences. France, Assemblée National Bulletin Mensual, 1 y 13:11.

Burrows, J., Tarling, R., Mackie, A., Lewis, R., \& Taylor, G. (2000). Review of Police Forces' Crime Recording Practices, Home Office Research Study 204. London: Home Office; Washington DC: U.S. Department of Justice.

Díez, J. L. (2004). El nuevo modelo penal de la seguridad ciudadana. Revista Electrónica de Ciencia Penal y Criminología. http://criminet.ugr.es/recpc

Downes, D., \& Morgan, R. (2012). Overtaking on the Left? The Politics of Law and Order in the Big Society. In M. Maguire, R. Morgan, \& R. Reiner (Eds.), Oxford Handbook of Criminology. Oxford: University Press. https://doi.org/10.1093/he/9780199590278.003.0007

Eurostat (2014). Trends in Crime and Criminal Justice, 2010. Eurostat.

Eurostat (2015). Social Statistics. Eurostat.

Farrell, G., Tilley, N., Tseloni, A., \& Mailley, J. (2010). Explaining and Sustaining the Crime Drop: Clarifying the Role of Opportunity-Related Theories. Crime Prevention and Community Safety, 12, 24-41. https://doi.org/10.1057/cpcs.2009.20 
Fitzgerald, J., Curtis, K. A., \& Corliss, C. (2012). Anxious Publics: Worries about Crime and Immigration. Comparative Political Studies, 45, 477-506. https://doi.org/10.1177/0010414011421768

Flatley, J., Kershaw, C., Smith, K., Chaplin, R., \& Moon, D. (2010). Crime in England and Wales 2009/10. London: Home Office Statistics Bulletin.

Greer, C., \& Reiner, R. (2012). Mediated Mayhem: Media, Crime, Criminal Justice. In M. Maguire, R. Morgan, \& R. Reiner (Eds.), Oxford Handbook of Criminology. Oxford: University Press. https://doi.org/10.1093/he/9780199590278.003.0009

Harrendorf, S., Heiskanen, M., \& Malby, S. (2010). International Statistics on Crime and Justice. Helsinki: Heuni-Unodc.

Hart, T., \& Rennison, C. (2003). Reporting Crime to the Police, 1992-2000. Bureau of Justice Statistics Special Report. Washington DC: U.S. Department of Justice.

Home Office (2005). Crime in England and Walles. Several Years. London: Home Office.

Home Office (2011). Criminal Statistics England and Wales (p. 28). Communication 5312. London: Home Office.

Hough, M., \& Sato, M. (2011). Trust in Justice: Why It Is Important for Criminal Policy, and How It Can Be Measured. Final Report of the Euro-Justis Project. Helsinki: Heuni-Unodc.

Huey, L., \& Quirouette, M. (2010). Any Girl Can Call the Cops, No Problem. British Journal of Criminology, 50, 278-295. https://doi.org/10.1093/bjc/azp078

Jones, S. (2009). Criminology. Oxford: Oxford University Press.

Kääriäinen, J., \& Siren, R. (2011). Trust in the Police, Generalized Trust and Reporting Crime. European Journal of Criminology, 8, 65-81. https://doi.org/10.1177/1477370810376562

Lewis, C. (2012). Crime and Justice Statistics Collected by International Agencies. European Journal on Criminal Policy and Research, 18, 5-21.

https://doi.org/10.1007/s10610-011-9164-9

Maguire, M. (2012). Crime Data and Statistic. In M. Maguire, R. Morgan, \& R. Reiner (Eds.), Oxford Handbook of Criminology (pp. 206-245). Oxford: Oxford University Press.

Malby, S. (2010). Data Collection on [New] Forms and Manifestations of Crime. In M. Joutsen (Ed.), New Types of Crime. Helsinki: Heuni-Unodc.

Mosher, C., Miethe, T., \& Hart, T. (2011). The Mismeasure of Crime. Los Angeles, CA: Sage. https://doi.org/10.4135/9781483349497

ONDRP (2012). Bulletin Pour l'année 2011.

ONS (Office for National Statistic) (2013a). Future Dissemination Strategy for the Publication on National Statistic on Crime in England and Wales (p. 5).

ONS (Office for National Statistic) (2013b). User Guide to Crime Statistic for England and Wales (p. 85-90).

Pandraud, R., \& Caresche, C. (2001). Rapport La Documentantion Francaise (p. 53).

Pérez, I., \& Benito, D. (2013). Estudio de los instrumentos existentes para medir la delincuencia. Revista Electrónica de Ciencia Penal y Criminología, 15, 1-15.

Pérez, J. L. (2012). Información sobre delincuencia generada por el programa Estadístico de seguridad del ministerio de Interior.

http://administracionelectronica.gob.es/pae.../Ponencia_054.pdf

Rennison, C. M., Gover, A. R., Bosick, S. J., \& Dodge, M. (2011). Reporting Violent Vic- 
timization to the Police: A Focus on Race/Hispanic Origin of the Victim among Adolescents. Open Family Studies Journal, 4, 54-67.

Robert, P., \& Zauberman, R. (2011). Mesurer la délinquance. Paris: Presses de Sciences Po.

Shute, J. (2013). Family Support as a Gang Reduction Measure. Children and Society, 27, 48-59. https://doi.org/10.1111/j.1099-0860.2011.00368.x

Tarling, R., \& Morris, K. (2010). Reporting Crime to the Police. British Journal of Criminology, 50, 474-490. https://doi.org/10.1093/bjc/azq011

Tournyol Du Clos, L., \& Rizk, C. (2004). Les chiffres mensuels des faits constatés par les services de pólice et les unités de gendarmerie (1ère partie). Résultats et methods, 3, 7-17.

Tseloni, A., Mailley, J., \& Tilley, N. (2010). Exploring the International Decline in Crime Rates. European Journal of Criminology, 7, 375-394.

https://doi.org/10.1177/1477370810367014

UK Statistics Authority (2010). Overcoming Barriers to Trust in Crime Statistics: England and Wales. Monitoring Report 5. London: UK Statistics Authority.

Ventre, A.-M., \& Bauer, A. (2011). Méthodologie des Tableaux de bords annuels de I'ONDRP. Bulletin pour l'année 2011. Observatoire National de la Délinquance et des réponses pénales.

Vollaard, B., \& Hamed, J. (2012). Why Police Have an Effect on Violent Crime after All Evidence from the British Crime Survey. Journal of Law and Economics, 55, 901-924. https://doi.org/10.1086/666614 